Article

\title{
Influence of Functional Group Concentration on Hypercrosslinking of Poly(vinylbenzyl chloride) PolyHIPEs: Upgrading Macroporosity with Nanoporosity
}

\author{
Amadeja Koler ${ }^{1}$, Mitja Kolar ${ }^{2}\left(\mathbb{D}\right.$, Karel Jeřábek $^{3}$ and Peter Krajnc ${ }^{1, *(\mathbb{D}}$ \\ 1 PolyOrgLab, Faculty of Chemistry and Chemical Engineering, University of Maribor, Smetanova 17, \\ SI-2000 Maribor, Slovenia; amadeja.koler@um.si \\ 2 Faculty of Chemistry and Chemical Technology, University of Ljubljana, Večna Pot 113, \\ SI-1000 Ljubljana, Slovenia; mitja.kolar@fkkt.uni-lj.si \\ 3 Institute of Chemical Process Fundamentals of the Czech Academy of Sciences, Rozvojova 2/135, CZ-165 02 \\ Prague, Czech Republic; jerabek@icpf.cas.cz \\ * Correspondence: peter.krajnc@um.si
}

check for

updates

Citation: Koler, A.; Kolar, M.; Jeřábek, K.; Krajnc, P. Influence of Functional Group Concentration on Hypercrosslinking of Poly(vinylbenzyl chloride) PolyHIPEs: Upgrading Macroporosity with Nanoporosity. Polymers 2021, 13, 2721. https:// doi.org/10.3390/polym13162721

Academic Editor: Vijay Kumar

Thakur

Received: 9 August 2021

Accepted: 13 August 2021

Published: 14 August 2021

Publisher's Note: MDPI stays neutral with regard to jurisdictional claims in published maps and institutional affiliations.

Copyright: (c) 2021 by the authors. Licensee MDPI, Basel, Switzerland. This article is an open access article distributed under the terms and conditions of the Creative Commons Attribution (CC BY) license (https:// creativecommons.org/licenses/by/ $4.0 /)$

\begin{abstract}
With the aim to study the influence of monomer ratio in poly(high internal phase emulsions) (polyHIPEs) on the polymer network architecture and morphology of poly(vinylbenzyl chloride-codivinylbenzene-co-styrene) after hypercrosslinking via the internal Friedel-Crafts process, polyHIPEs with $80 \%$ overall porosity were prepared at three different initial crosslinking degrees, namely 2,5 , and $10 \mathrm{~mol} \%$. All had typical interconnected cellular morphology, which was not affected by the hypercrosslinking process. Nitrogen adsorption and desorption experiments with BET and $t$-plot modelling were used for the evaluation of the newly introduced nanoporosity and in combination with elemental analysis for the evaluation of the extent of the hypercrosslinking. It was found that, for all three initial crosslinking degrees, the minimum amount of functional monomer, 4-vinylbenzyl chloride, was approximately $30 \mathrm{~mol} . \%$. Hypercrosslinking of polymers with lower concentrations of functional monomer did not result in induction of nanoporosity while the initial crosslinking degree had a much lower impact on the formation of nanoporosity.
\end{abstract}

Keywords: polyHIPE; hypercrosslinking; poly(4-vinylbenzyl chloride); hierarchically porous polymers; nanoporosity; macroporosity

\section{Introduction}

The concept of polymer chain hypercrosslinking was introduced by Davankov, Rogoshin and Tsyurupa, using linear polystyrene or swollen gel-type poly (styrene-codivinylbenzene) in the presence of an external crosslinker, solvent and a Lewis base as a catalyst [1]. The result of the reaction was a three-dimensional rigid network with short and rigid connections. Generally, hypercrosslinked polymers are prepared by postpolymerisation crosslinking of long polymer chains in a swollen polymer matrix creating numerous new links. In the case of chloromethylated polystyrene, polymer chains are reacted with a Friedel-Crafts catalyst in a swelling solvent. This creates new connections by converting chloromethyl groups into methylene bridges that interconnect polymer chains resulting in the formation of micropores. Through further stages of the hypercrosslinking process, the crosslinking increases and, therefore, after solvent removal, a stable microporous network is formed [2,3]. The hypercrosslinked polymers may collapse during drying however reinforcement of their skeleton with additional crosslinks enables their re-expansion both with polar and non-polar solvents [4,5]. Hypercrosslinked polymers contain a very high density of crosslinks together with micropores and exhibit high surface area (up to $2000 \mathrm{~m}^{2} / \mathrm{g}$ ) [4,6].

The main difference between a post-polymerisation hypercrosslinking and copolymerisation crosslinking is in the pore formation method. In copolymerisation crosslinking, 
pores are formed due to phase separation during polymerisation between the monomer and the crosslinker, in the presence of an inert diluent. The result is the formation of a two-phase heterogeneous system where one phase represents a crosslinked polymer and the other excess diluent and possibly unpolymerised monomers. Usually, phase separation occurs near the gel point and can appear as macrosyneresis [7] when the fluid and a swollen gel make two continuous phases. Resulting macroreticular polymers have a cauliflower-like morphology [8-10], with pores as spaces in clusters of crosslinked polymer nodules. Such polymers usually exhibit relatively modest specific surface area and somehow poorer mechanical stability [11] than their gel-type counterparts do. Postpolymerisation crosslinking-hypercrosslinking performed on swollen polymers induces the formation of additional porosity and increases rigidity of the polymer matrix which improves its compatibility with both thermodynamically good and bad solvents $[5,12]$ and thus improve the accessibility of reactive sites. Therefore, hypercrosslinked polymers are used as separation columns [13-16], adsorbents [17-21], solid state supports for catalysts [22-24], to name the most frequent applications.

On the other hand, macroporous polymers in monolithic form can be obtained by the polymerisation of a continuous phase of high internal phase emulsion (polyHIPE) [25-28]. The internal (or droplet) phase is dispersed in the continuous phase of the emulsion and represents at least $74.05 \%$ of the total volume of the emulsion in the uniform packing of monodispersed droplets, or $64 \%$ in the case of random packing [29]. Most common are water-in-oil HIPEs, where the continuous phase consists of monomers, surfactants and initiator, while the internal phase is aqueous. After the polymerisation of the continuous phase, the droplet phase is removed, and macro pores are thus formed. The internal topology of polymeric material prepared in this way has two levels of pores, the primary pores, and secondary, interconnecting pores. PolyHIPEs have so far found numerous applications such as tissue engineering [30-33], as columns in separation systems [34-38], as supports for catalysts $[6,39,40]$ etc.

Hypercrosslinking of 4-vinylbenzyl chloride (VBC)-based polyHIPEs results in rigid polymers with induced microporosity in macro porous material, which leads to very high specific surface areas and better compatibility with solvents. This makes the sites within such a hierarchically porous polymer more accessible. In flow systems, macro pores allow for reduced back pressure and faster mass transfer, while micro and meso pores lead to an increase in specific surface area and thus greater availability of reactive sites. It was demonstrated that polyHIPEs can be hypercrosslinked even without the introduction of functional monomer e.g., VBC [41]; however, a more efficient method for creating additional crosslinking is based on the Friedel-Crafts catalysed transformation of chloromethyl groups into crosslinking methylene bridges [8]. A convenient way to introduce chloromethyl groups into styrenic polymers is admixture of VBC to the mixture of co-monomers. Schwab et al. [42] prepared hypercrosslinked VBC/DVB polyHIPEs with a DVB content between 2.5 and 40 mol.\%. After hypercrosslinking, the surface area increased significantly (to $1200 \mathrm{~m}^{2} / \mathrm{g}$ ), while the polyHIPE morphology remained unchanged. The materials showed to be promising for n-butane storage. In another study VBC based polyHIPEs with $2 \mathrm{~mol} \%$ DVB content were used for controlled hypercrosslinking to leave some unreacted benzyl chloride groups for further binding of MAP (methyl amino pyridine) [6]. Monolithic VBC polyHIPE was found to be a very effective nucleophilic catalyst. Porous carbon with a high BET specific surface area and hierarchical porous structure was synthesised by pyrolysis of hypercrosslinked VBC/DVB polyHIPE [43]. Hypercrosslinking generated micro pores to limit the degradation of polyHIPE morphology after pyrolysis.

Despite a lot of research on post-polymerisation hypercrosslinking of VBC based polymers and numerous applications (see Reference [44] for a recent review), there is a lack of information about the influence of VBC polymer chain concentration and of initial crosslinking degree on the post-polymerisation crosslinking process. Herein, we report the results of the study applying VBC based polyHIPEs with various initial crosslinking degrees in the process of a Friedel-Crafts type post-polymerisation hypercrosslinking process. 


\section{Materials and Methods}

\subsection{Materials}

We purified 4-vinylbenzyl chloride (VBC, 90\%, Sigma Aldrich, St. Louis, MO, USA), styrene (STY, Sigma Aldrich) and divinylbenzene (DVB, 80\%, composed of $80 \%$ of divinylbenzene and $20 \%$ of ethylvinylbenzene, Sigma Aldrich) by passing them through a layer of aluminium oxide (Fischer Chemical, Guangzhou, China) to remove the inhibitors. Sorbitan monooleate (Span 80, Sigma Aldrich), $\alpha, \alpha^{\prime}$-azo-bisisobutyronitrile (AIBN, Fluka, Buchs, Switzerland), acetone (Sigma Aldrich), methanol (Sigma Aldrich), 1,2-dichloroethane (DCE, 99,5\%, Sigma Aldrich), nitric acid $\left(\mathrm{HNO}_{3}, 63 \%\right.$, Carlo Erba, Sabadell, Spain), calcium chloride hexahydrate $\left(\mathrm{CaCl}_{2} \cdot 6 \mathrm{H}_{2} \mathrm{O}\right.$, Sigma Aldrich) were used as received.

\subsection{Preparation of 4-Vinylbenzyl Chloride/Divinylbenzene/Styrene Poly(High Internal Phase Emulsions) (PolyHIPEs)}

An internal phase consisting of a $1.76 \%$ aqueous solution of $\mathrm{CaCl}_{2} \cdot 6 \mathrm{H}_{2} \mathrm{O}$ was added dropwise under constant stirring to a continuous phase, consisting of 4-vinylbenzyl chloride (VBC), styrene (STY) and divinylbenzene (DVB) monomers (at different molar ratios, see Table 1), surfactant Span 80 (20 vol\% with regards to monomers) and initiator AIBN (1 wt.\% with regards to monomers). The emulsion was stirred for a further $60 \mathrm{~min}$ after the addition of the internal phase at $250 \mathrm{rpm}$ and then poured into polypropylene moulds and transferred to the oven for $24 \mathrm{~h}$ at $60{ }^{\circ} \mathrm{C}$ to complete the polymerisation. After polymerisation, the monoliths were purified by Soxhlet extraction $(24 \mathrm{~h}$ in deionized water and $24 \mathrm{~h}$ in acetone) and then air-dried. The polyHIPEs are labelled according to their DVB content (A 2 mol.\%, B 5 mol.\% and C 10 mol.\%), and the molar percentage of VBC in the monomer mixture. Detailed information on the monomer mixture composition is given in Table 1.

Table 1. Composition of poly (4-vinylbenzyl chloride (VBC)/divinylbenzene (DVB)/ styrene (STY)) poly(high internal phase emulsions) (polyHIPE) samples.

\begin{tabular}{|c|c|c|c|c|c|}
\hline \multirow{2}{*}{ Sample } & \multicolumn{3}{|c|}{ Continuous Phase } & \multirow{2}{*}{$\begin{array}{l}\mathrm{V}_{\mathrm{AP}} \\
{[\mathrm{mL}]}\end{array}$} & \multirow{2}{*}{$\begin{array}{c}\text { m (Span 80) } \\
{[\mathrm{g}]}\end{array}$} \\
\hline & m (STY) [g] & m (DVB) [g] & $\mathrm{m}(\mathrm{VBC})[\mathrm{g}]$ & & \\
\hline A93 & 0.181 & 0.095 & 4.747 & 18.6 & 1.264 \\
\hline A73 & 0.899 & 0.086 & 3.724 & 17.9 & 1.185 \\
\hline A53 & 1.563 & 0.107 & 2.696 & 17.2 & 1.162 \\
\hline A43 & 1.909 & 0.106 & 2.225 & 16.9 & 1.035 \\
\hline A41 & 1.98 & 0.091 & 2.104 & 16.8 & 0.83 \\
\hline A38 & 2.091 & 0.111 & 1.936 & 16.8 & 0.834 \\
\hline A36 & 2.111 & 0.450 & 1.539 & 16.7 & 0.887 \\
\hline A33 & 2.253 & 0.087 & 1.679 & 16.5 & 1.005 \\
\hline B90 & 0.173 & 0.257 & 4.579 & 18.6 & 1.339 \\
\hline B70 & 0.877 & 0.218 & 3.567 & 17.9 & 1.199 \\
\hline B50 & 1.583 & 0.234 & 2.573 & 17.2 & 1.089 \\
\hline B40 & 1.926 & 0.258 & 2.035 & 16.9 & 1.076 \\
\hline B38 & 1.98 & 0.217 & 1.933 & 16.8 & 0.916 \\
\hline B35 & 2.096 & 0.246 & 1.794 & 16.7 & 0.817 \\
\hline B33 & 2.187 & 0.226 & 1.630 & 16.6 & 0.815 \\
\hline B30 & 2.279 & 0.221 & 1.532 & 16.5 & 1.035 \\
\hline C85 & 0.188 & 0.440 & 4.372 & 18.6 & 1.227 \\
\hline C65 & 0.566 & 0.498 & 3.858 & 18.3 & 1.194 \\
\hline $\mathrm{C} 45$ & 1.223 & 0.457 & 2.814 & 17.6 & 1.122 \\
\hline C35 & 1.922 & 0.443 & 1.788 & 16.9 & 1.087 \\
\hline C33 & 1.978 & 0.438 & 1.678 & 16.8 & 0.835 \\
\hline C28 & 2.196 & 0.458 & 1.386 & 16.6 & 0.814 \\
\hline C25 & 2.256 & 0.460 & 1.290 & 16.4 & 0.993 \\
\hline
\end{tabular}

*Volume of the aqueous phase. Samples A:2 mol.\% DVB, B: 5 mol.\% DVB, C:10 mol.\% DVB. 


\subsection{Hypercrosslinking of PolyHIPEs}

A powdered polyHIPE sample $(1 \mathrm{~g})$ was added to a two-necked round-bottom flask, along with $80 \mathrm{~mL}$ of 1,2-dichloroethane. After stirring and purging with nitrogen for $15 \mathrm{~min}$, the mixture was stirred for a further $45 \mathrm{~min}$ to allow the sample to swell. $\mathrm{A} \mathrm{FeCl}_{3}$ catalyst (relative to the calculated chloromethyl groups) was added through the neck of the flask, which was placed on an ice bath. This was followed by a 15 min nitrogen purge and then a $45 \mathrm{~min}$ constant stirring under nitrogen atmosphere. The flask was then placed on an oil bath at $80^{\circ} \mathrm{C}$. After $20 \mathrm{~min}$, the sample was removed from the oil bath and the reaction was quenched by the addition of $40 \mathrm{~mL}$ of methanol. Hypercrosslinked polyHIPEs were washed with methanol and $0.1 \mathrm{M} \mathrm{HNO}_{3}(3 \times 20 \mathrm{~mL}$ of each). The final products were purified by Soxhlet extraction in acetone for $24 \mathrm{~h}$ and air-dried.

\subsection{Characterization}

Nitrogen adsorption/desorption measurements were done on a Micromeritics TriStar II 3020 (Norcross, GA, USA) porosimeter using the manufacturer's software.

SEM pictures were taken on a Phillips XL-30 SEM (Leuven, Belgium) operating at $20 \mathrm{kV}$. Samples were platinum coated using ion sputter Jeol JCF-1100E (Tokyo, Japan) for $2 \mathrm{~min}$ at $40 \mathrm{~mA}$.

Chlorine content was determined as follows: after homogenization of the samples, a small amount of the sample, typically $1 \mathrm{mg}$, was weighed into a sillica holder and transferred to an AOX combustion tube. The samples were combusted using a Haberkorn/Braun M 2000C instrument (Dietikon, Switzerland) in an oxygen atmosphere at $950{ }^{\circ} \mathrm{C}$, converting the chlorine to chloride ions. The final amount of chloride was determined by an automated coulometric titration. Analyses were performed in triplicate.

\section{Results}

\subsection{Preparation of Poly (VBC-co-DVB-co-STY)HIPEs}

Poly(VBC-co-DVB-co-STY)HIPEs were prepared with varied ratios of VBC, DVB, and STY monomers (Figure 1). Using free radical polymerisation initiated by AIBN, polyHIPE monoliths with three different crosslinking degrees were synthesized. Firstly, the influence of initial DVB-caused crosslinking, on the degree of hypercrosslinking, was evaluated. For this purpose, 2, 5 and 10 mol.\% of DVB were used as initial crosslinking degree. Rather low degrees of initial crosslinking was used as it was expected that the rigidity of the polymer network would have a substantial diminishing effect on the post polymerisation hypercrosslinking process. Most examples from the literature describe a Friedel-Crafts type of hypercrosslinking performed on poly(4-vinylbenzyl chloride) with a low degree of crosslinking, up to 5 mol. $\%[4,6,45,46]$, while much less is known on this type of hypercrosslinking of networks with higher degree of crosslinking. Furthermore, we were interested in how the concentration of the hypercrosslinking monomer, in our case 4-vinylbenzyl chloride, influences the hypercrosslinking process. As the process involves a reaction between the neighboring functional groups, it is expected that the distribution of functional groups within the polymer network would have a significant effect on the formation of crosslinks during the hypercrosslinking process. Therefore, the experimental design included variation of both initial crosslinking degree (DVB content) and "dilution" of functional groups i.e., the ratio of functional to "diluting" monomer (styrene was used for this purpose). It was assumed that all added DVB to the monomer mixture was crosslinking as the highest addition of DVB was $10 \mathrm{~mol} \%$. Three series of experiments were performed, one for each initial crosslinking degree (Table 1). In addition to DVB, STY was added to each batch (from 5 to $65 \mathrm{~mol} \%$ of monomers, Table 1), and the rest was VBC. Chloromethyl functional groups in the monomeric system was diluted with the addition of STY to obtain different VBC contents at the same initial crosslinking degrees, which proved to be an important factor in further hypercrosslinking studies of synthesized polyHIPEs. 

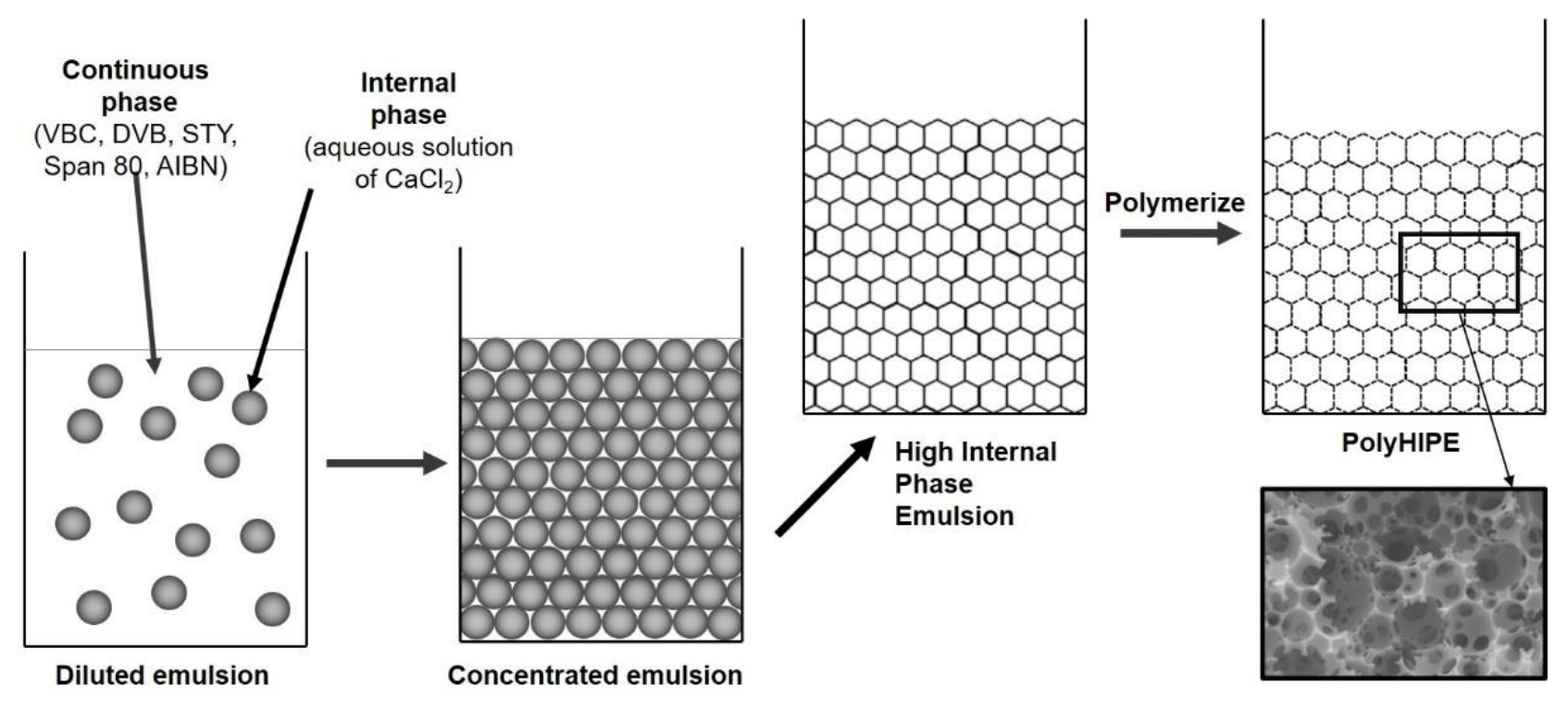

Figure 1. PolyHIPE preparation.

The kinetic stability of the emulsion is extremely important for the formation of polyHIPE monoliths and was achieved with the addition of $20 \mathrm{wt} . \%$ of the surfactant Span 80 (HLB = 4.3) from the oleate family of surfactants, which is suitable for reducing the interfacial tension in $\mathrm{w} / \mathrm{o}$ emulsions. With the addition of surfactant, stable HIPEs and polyHIPEs were obtained with typical interconnecting open cell polyHIPE morphology and average diameter of primary pores between 5 and $10 \mu \mathrm{m}$.

\subsection{Hypercrosslinking of PolyHIPEs}

Hypercrosslinking of polyHIPEs was performed by an established procedure, applying a Friedel-Crafts type electrophilic aromatic substitution process [6]. Generally, a chloromethyl group tethered to the polymer chain can react either with a benzene ring or another VBC moiety creating methylene bridges or cyclical type connections. DCE has been used as a solvent in which styrene-type polymers are swollen, while being effective in dissolving $\mathrm{FeCl}_{3}$, which serves as a catalyst for Friedel-Crafts alkylation reactions. The effect of this procedure was apparent both in the drop of chlorine content due to conversion of a part of chloromethyl groups into crosslinking methylene bridges and in a substantial increase of the BET surface area (Table 2).

In most cases, the residual chlorine content after hypercrosslinking was 10-15 wt.\%. Somewhat surprisingly, higher values of residual chlorine (suggesting lower efficiency of the hypercrosslinking) were found in samples with the highest VBC or DVB content. In these samples, there is greater probability that within the polymer network some chloromethyl groups could be located in less accessible places. A very profound effect of the hypercrosslinking is evident in the surface area values. Before hypercrosslinking all the polymers exhibited low surface area only, corresponding with the area of the macro pores created by emulsification of the monomer mixture. The hypercrosslinking porosity modification does not modify the macroporous polyHIPE features (Figure 2). 
Table 2. Hypercrosslinking effects.

\begin{tabular}{cccccc}
\hline \multirow{2}{*}{ Sample } & \multicolumn{2}{c}{ Before Hypercrosslinking } & \multicolumn{3}{c}{ After Hypercrosslinking } \\
\cline { 2 - 6 } & $\begin{array}{c}\text { Cl Content, } \\
\text { wt. } \%\end{array}$ & $\begin{array}{c}\text { BET Surf. } \\
\text { Area, } \mathbf{~ m}^{\mathbf{2}} \mathbf{g}\end{array}$ & $\begin{array}{c}\text { Cl Content, } \\
\text { wt. } \%\end{array}$ & $\begin{array}{c}\text { Residual Cl, } \\
\text { \% of Orig. }\end{array}$ & $\begin{array}{c}\text { BET Surf. } \\
\text { Area, } \mathbf{~ m}^{2} \text { /g }\end{array}$ \\
\hline A93 & $21.90 \pm 0.20$ & 2.40 & $3.70 \pm 0.03$ & 16.9 & 709 \\
A73 & $18.00 \pm 0.40$ & 3.20 & $1.70 \pm 0.03$ & 9.4 & 636 \\
A53 & $13.90 \pm 0.20$ & 4.60 & $1.80 \pm 0.10$ & 12.9 & 410 \\
A43 & $11.70 \pm 0.10$ & 1.80 & $1.00 \pm 0.02$ & 8.5 & 279 \\
A41 & $11.20 \pm 0.30$ & 2.30 & $2.00 \pm 0.10$ & 17.9 & 304 \\
A38 & $10.30 \pm 0.30$ & 3.00 & $1.40 \pm 0.20$ & 13.6 & 122 \\
A36 & $8.20 \pm 0.10$ & 3.10 & $1.30 \pm 0.10$ & 15.9 & 5.0 \\
A33 & $9.20 \pm 0.20$ & 3.90 & $0.60 \pm 0.03$ & 6.5 & 3.9 \\
\hline B90 & $21.30 \pm 0.60$ & 4.40 & $7.50 \pm 0.40$ & 35.2 & 585 \\
B70 & $17.80 \pm 0.40$ & 6.00 & $2.70 \pm 0.10$ & 15.2 & 491 \\
B50 & $13.70 \pm 0.20$ & 4.80 & $1.70 \pm 0.04$ & 12.4 & 412 \\
B40 & $11.00 \pm 0.30$ & 2.30 & $1.10 \pm 0.10$ & 10.0 & 196 \\
B38 & $10.40 \pm 0.10$ & 3.10 & $1.20 \pm 0.10$ & 11.5 & 217 \\
B35 & $9.60 \pm 0.10$ & 2.30 & $1.40 \pm 0.10$ & 14.6 & 70 \\
B33 & $8.90 \pm 0.50$ & 3.40 & $1.10 \pm 0.10$ & 12.4 & 8.0 \\
B30 & $8.30 \pm 0.20$ & 3.00 & $0.80 \pm 0.10$ & 9.6 & 4.2 \\
\hline C85 & $20.40 \pm 0.50$ & 2.20 & $4.10 \pm 0.03$ & 20.1 & 536 \\
C65 & $18.20 \pm 0.30$ & 3.80 & $2.30 \pm 0.10$ & 12.6 & 547 \\
C45 & $14.30 \pm 0.20$ & 3.60 & $1.50 \pm 0.07$ & 10.5 & 350 \\
C35 & $9.60 \pm$ & 2.10 & $1.20 \pm 0.03$ & 12.5 & 62 \\
C33 & $9.20 \pm 0.10$ & 2.60 & $1.40 \pm 0.10$ & 15.2 & 14 \\
C28 & $7.60 \pm 0.50$ & 3.10 & $0.80 \pm 0.10$ & 10.5 & 14 \\
C25 & $7.10 \pm 0.40$ & 1.80 & $1.00 \pm 0.10$ & 14.1 & 13 \\
\hline Sa & & & & \\
\hline
\end{tabular}

Samples A: 2 mol.\% DVB, B: 5 mol.\% DVB, C:10 mol.\% DVB.
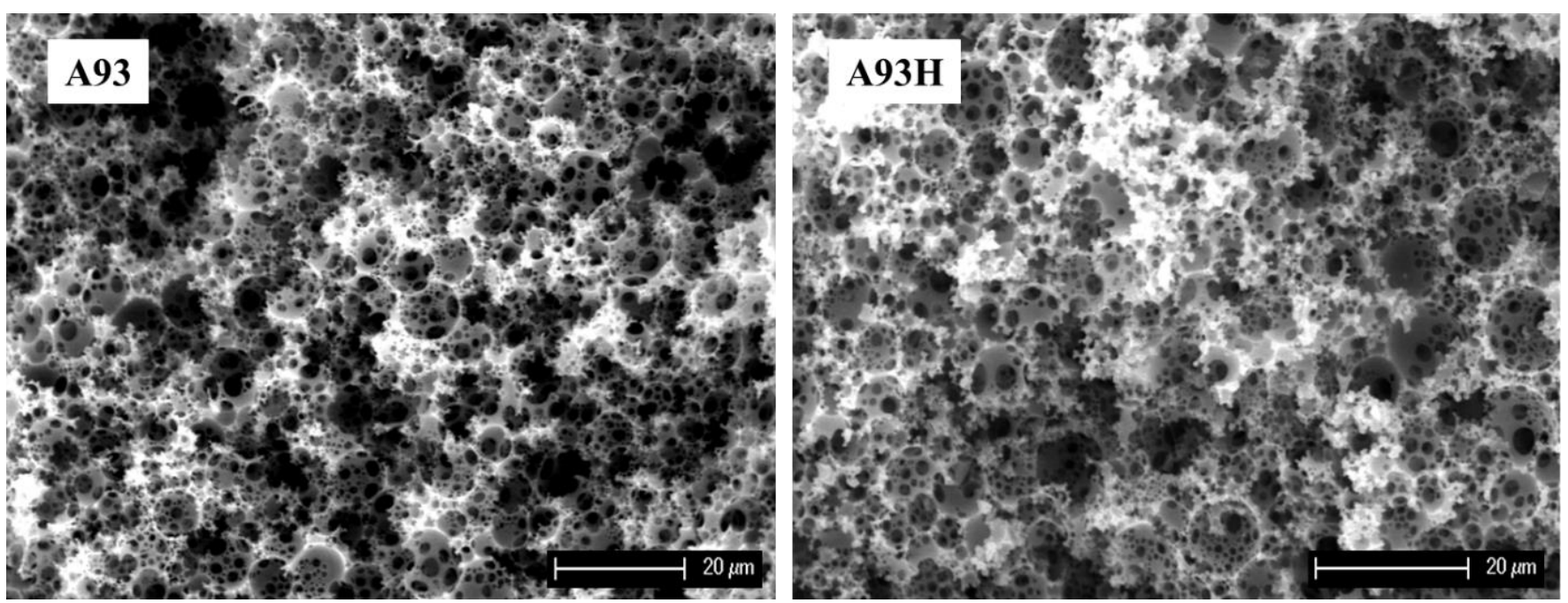

Figure 2. Scanning electron micrographs of polyHIPE samples A93 and A93H.

Substantially higher BET surface of the hypercrosslinked polymers indicates the formation of new porosity. However, hypercrosslinking is known to produce microporosity with pores smaller than $2 \mathrm{~nm}$ [47]. Such narrow pores are filled with the sorbate sooner than the BET equation-described multilayer adsorption begins. Standard evaluation of the BET surface of such materials interprets the sorbate amount filling the micropores as a part of the BET multilayer, which produces incorrect BET surface area data. It is possible to distinguish between micropore volume and external surface area using the $t$-plot method, which is plotting the adsorbed amount against thickness of the adsorbed layer computed 
from adsorption on a flat surface. The software used in this study is based on the Harkins and Jura thickness equation [48]. The linear part of such a plot (usually corresponding to relative pressures $0.05-0.35$ ) can be considered as the region of the adsorption on flat surface. The Y-intercept of such a line corresponds to the micropore volume and the slope is proportional to the external (outside micropores) surface area [49].

T-plot analyses of the polymers before hypercrosslinking show zero or slightly negative values of the micropore volumes $\left(-0.008-0 \mathrm{~cm}^{3} / \mathrm{g}\right)$ and external surface areas in the range of $0.8-8.8 \mathrm{~m}^{2} / \mathrm{g}$, slightly higher than the BET surfaces. However, considering the completely different theoretical background of these two methods, the agreement is very good. In the hypercrosslinked polymers, both the amount of micropores and the external surface area varied in dependence of the VBC content of the polymer (Figure 3).
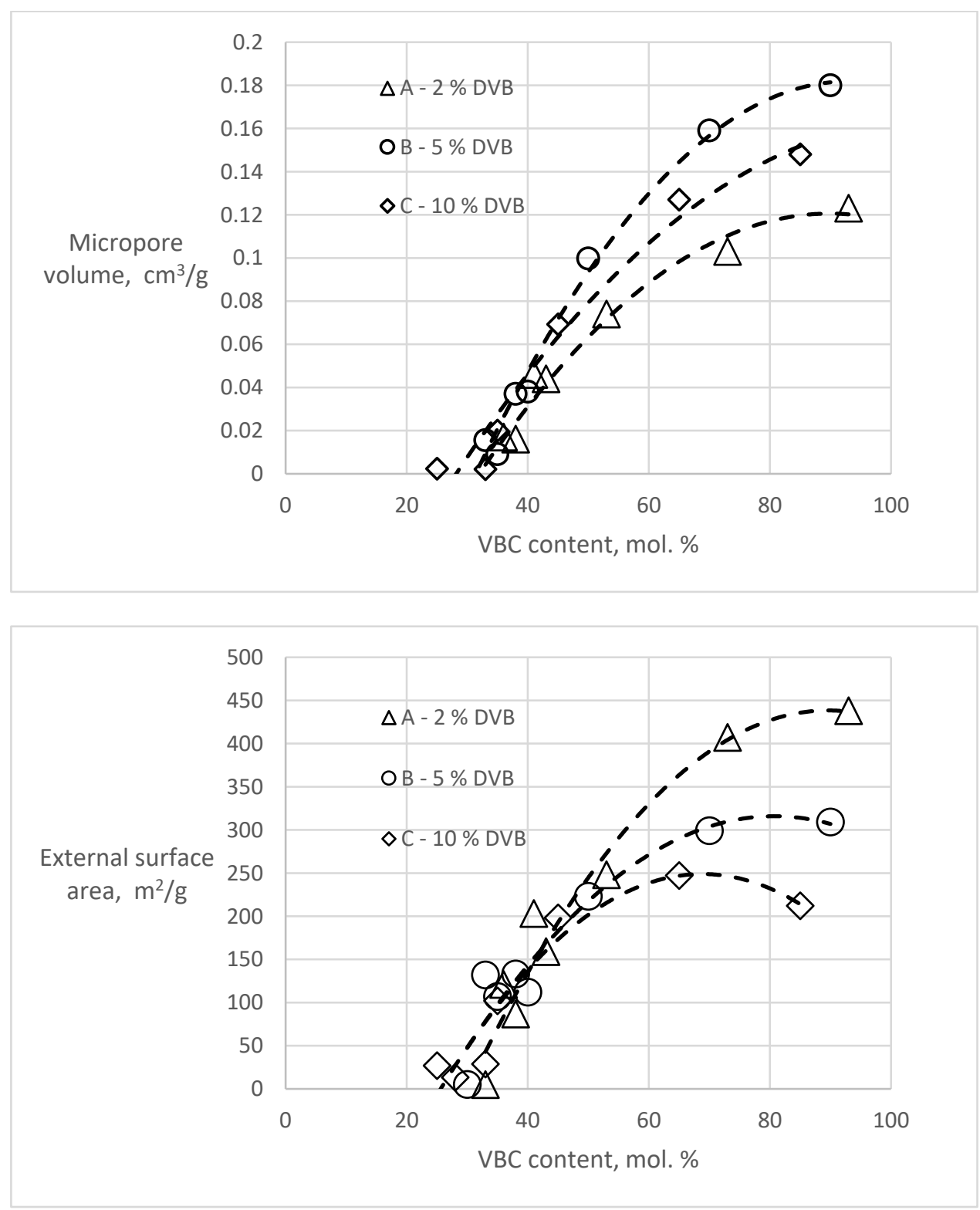

Figure 3. Dependencies of micropore volume and external surface area in the hypercrosslinked polymers on the content of VBC.

Both dependencies show that for the formation of new porosity, the presence of chloromethyl groups in about one third of the monomer units is needed. With increasing VBC concentration, both the micropore volume and the external (mesopore) surface area 
increase. The character of the newly created porosity and the effect of the DVB content in the starting polymers is most apparent in the samples A93, B90 and C85 having the highest VBC content in the series (Table 3). It is evident that with an increase of the DVB content (crosslinking) of the starting polymer the total volume of the hypercrosslinkinggenerated pore volume decreases. An increase of the crosslinking of the starting polymer also influences the pore size distribution. While with $2 \mathrm{~mol} . \%$ DVB in the starting polymer the micropores formed in the hypercrosslinked material represent only about one quarter of the newly formed porosity, in the hypercrosslinked polymer C85 containing $10 \mathrm{~mol} \%$ DVB they represent half of the total porosity.

Table 3. Comparison of micro- and meso-porosity created by hypercrosslinking.

\begin{tabular}{ccccc}
\hline Sample & $\mathbf{V}_{\mathbf{p}}\left[\mathbf{c m}^{3} / \mathbf{g}\right]$ & $\mathbf{V}_{\text {micro }}\left[\mathbf{c m}^{3} / \mathbf{g}\right]$ & $\mathbf{V}_{\text {meso }}\left[\mathbf{c m}^{3} / \mathbf{g}\right]$ & $\mathbf{V}_{\text {micro }} / \mathbf{V}_{\mathbf{p}}$ \\
\hline A93 (2 mol.\% DVB) & 0.43 & 0.12 & 0.31 & 0.28 \\
B90 (5 mol.\% DVB) & 0.40 & 0.18 & 0.22 & 0.45 \\
C85 (10 mol.\% DVB) & 0.30 & 0.15 & 0.15 & 0.50 \\
\hline
\end{tabular}

\section{Conclusions}

Concentration of functional groups has been shown to have a significant effect on the hypercrosslinking process of vinylbenzyl chloride-based polyHIPEs. The strong influence of VBC concentration is evident at all the three initial crosslinking degrees. The VBC content of about 30 mol.\% appears to be a critical value above which starts the formation of new pores having dimensions from micropore $(<2 \mathrm{~nm})$ to mesopore (tens of $\mathrm{nm}$ ). Pore formation during hypercrosslinking proceeds within swollen polymer gel by a gradual increase of the local polymer chain density probably inducing phase separation in the form of liquid droplets within a continuous polymer matrix that is by microsyneresis. Hence, the more swollen the starting polymer is (the lower is its DVB content) the greater the volume of new pores can be created. The level of the DVB content in the starting polymer also influences the pore size distribution of the created pores which is evident in the increase of the share of micropores with the increase of the DVB content. The results shed more light on the Friedel-Crafts hypercrosslinking process in polyHIPEs, allowing for more control of the microstructure and the preparation of polymer materials with controlled morphology on several porosity levels.

Author Contributions: Conceptualization, A.K. and P.K.; writing-original draft preparation, A.K.; writing-review and editing, P.K. and K.J.; formal analysis, A.K., K.J. and M.K.; funding acquisition, P.K., supervision, P.K.; project administration, P.K. All authors have read and agreed to the published version of the manuscript.

Funding: This research was funded by Javna agencija za raziskovalno dejavnost Republike Slovenije (Slovenian Research Agency), grant number P2-0006, P1-0153, and scholarship to A.K.

Institutional Review Board Statement: Not applicable.

Informed Consent Statement: Not applicable.

Data Availability Statement: Not applicable.

Conflicts of Interest: The authors declare no conflict of interest.

\section{References}

1. Davankov, V.A.; Rogozhin, V.; Tsyurupa, M.P. Macronet Polystyrene Structures for Ionites and Method of Producing Same. U.S. Patent 3,729,457, 24 April 1973.

2. Tsyurupa, M.P.; Davankov, V.A. Hypercrosslinked polymers: Basic principle of preparing the new class of polymeric materials. React. Funct. Polym. 2002, 53, 193-203. [CrossRef]

3. Veverka, P.; Jeřábek, K. Influence of hypercrosslinking on adsorption and absorption on or in styrenic polymers. React. Funct. Polym. 2004, 59, 71-79. [CrossRef] 
4. Ahn, J.H.; Jang, J.E.; Oh, C.G.; Ihm, S.K.; Cortez, J.; Sherrington, D.C. Rapid generation and control of microporosity, bimodal pore size distribution, and surface area in Davankov-type hyper-cross-linked resins. Macromolecules 2006, 39, 627-632. [CrossRef]

5. Veverka, P.; Jeřábek, K. Mechanism of hypercrosslinking of chloromethylated styrene- divinylbenzene copolymers. React. Funct. Polym. 1999, 41, 21-25. [CrossRef]

6. Pulko, I.; Wall, J.; Krajnc, P.; Cameron, N.R. Ultra-high surface area functional porous polymers by emulsion templating and hypercrosslinking: Efficient nucleophilic catalyst supports. Chem. A Eur. J. 2010, 16, 2350-2354. [CrossRef]

7. Dušek, K. Phase separation during the formation of three-dimensional polymers. J. Polym. Sci. Part B Polym. Lett. 1965, 3, $209-212$. [CrossRef]

8. Okay, O. Macroporous copolymer networks. Prog. Polym. Sci. 2000, 25, 711-779. [CrossRef]

9. Tsyurupa, M.P.; Davankov, V.A. Porous structure of hypercrosslinked polystyrene: State-of-the-art mini-review. React. Funct. Polym. 2006, 66, 768-779. [CrossRef]

10. Sherrington, D.C. Preparation, structure and morphology of polymer supports. Chem. Commun. 1998, 2275-2286. [CrossRef]

11. Sherrington, D.C.; Hodge, P. Synthesis Separations Using Functional Polymers; Wiley-VCH Verlag GmbH\&Co. KGaA: Chichester, $\mathrm{UK}, 1988$.

12. Pastukhov, A.V.; Tsyurupa, M.P.; Davankov, V.A. Hypercrosslinked polystyrene: A polymer in a non-classical physical state. J. Polym. Sci. Part B Polym. Phys. 1999, 37, 2324-2333. [CrossRef]

13. Davankov, V.A.; Tsyurupa, M.P.; Ilyin, M.; Pavlova, L. Hypercross-linked polystyrene and its potentials for liquid chromatography: A mini-review. J. Chromatogr. A 2002, 965, 65-73. [CrossRef]

14. Davankov, V.A.; Sychov, C.S.; Ilyin, M.M.; Sochilina, K.O. Hypercrosslinked polystyrene as a novel type of high-performance liquid chromatography column packing material: Mechanisms of retention. J. Chromatogr. A 2003, 987, 67-75. [CrossRef]

15. Penner, N.A.; Nesterenko, P.N.; Hyin, M.M.; Tsyurupa, M.P.; Davankov, V.A. Investigation of the properties of hypercrosslinked polystyrene as a stationary phase for high-performance liquid chromatography. Chromatographia 1999, 50, 611-620. [CrossRef]

16. Urban, J.; Svec, F.; Fréchet, J.M.J. Hypercrosslinking: New approach to porous polymer monolithic capillary columns with large surface area for the highly efficient separation of small molecules. J. Chromatogr. A 2010, 1217, 8212-8221. [CrossRef]

17. Yang, Y.; Tan, B.; Wood, C.D. Solution-processable hypercrosslinked polymers by low cost strategies: A promising platform for gas storage and separation. J. Mater. Chem. A 2016, 4, 15072-15080. [CrossRef]

18. Liu, Q.; Xia, B.; Huang, J.; Liao, B.; Liu, H.; Ou, B.; Chen, L.; Zhou, Z. Hypercrosslinked polystyrene microspheres with ultrahigh surface area and their application in gas storage. Mater. Chem. Phys. 2017, 199, 616-622. [CrossRef]

19. Belyakova, L.D.; Schevchenko, T.I.; Davankov, V.A.; Tsyurupa, M.P. Sorption of vapors of various substances by hypercrosslinked "styrosorb" polystyrenes. Adv. Colloid Interface Sci. 1986, 25, 249-266. [CrossRef]

20. Tsyurupa, M.P.; Maslova, L.A.; Andreeva, A.I.; Mrachkovskaya, T.A.; Davankov, V.A. Sorption of organic compounds from aqueous media by hypercrosslinked polystyrene sorbents 'Styrosorbrs'. React. Polym. 1995, 25, 69-78. [CrossRef]

21. Davankov, V.A.; Pavlova, L.; Tsyurupa, M.P.; Brady, J.; Balsamo, M.; Yousha, E. Polymeric adsorbent for removing toxic proteins from blood of patients with kidney failure. J. Chromatogr. B Biomed. Sci. Appl. 2000, 739, 73-80. [CrossRef]

22. Wang, K.; Jia, Z.; Yang, X.; Wang, L.; Gu, Y.; Tan, B. Acid and base coexisted heterogeneous catalysts supported on hypercrosslinked polymers for one-pot cascade reactions. J. Catal. 2017, 348, 168-176. [CrossRef]

23. Gu, Y.; Son, S.U.; Li, T.; Tan, B. Low-Cost Hypercrosslinked Polymers by Direct Knitting Strategy for Catalytic Applications. Adv. Funct. Mater. 2021, 31, 1-24. [CrossRef]

24. Liu, X.; Xu, W.; Xiang, D.; Zhang, Z.; Chen, D.; Hu, Y.; Li, Y.; Ouyang, Y.; Lin, H. Palladium immobilized on functionalized hypercrosslinked polymers: A highly active and recyclable catalyst for Suzuki-Miyaura coupling reactions in water. New J. Chem. 2019, 43, 12206-12210. [CrossRef]

25. Barby, D.; Haq, Z. Low Density Porous Cross-Linked Polymeric Material Sand Their Preparation. EP Patent 60138, 6 November 1985.

26. Pulko, I.; Krajnc, P. Porous Polymer Monoliths by Emulsion Templating. Encycl. Polym. Sci. Technol. 2017, 1-28. [CrossRef]

27. Cameron, N.R. High internal phase emulsion templating as a route to well-defined porous polymers. Polymer 2005, 46, 1439-1449. [CrossRef]

28. Zhang, T.; Sanguramath, R.A.; Israel, S.; Silverstein, M.S. Emulsion Templating: Porous Polymers and Beyond. Macromolecules 2019, 52, 5445-5479. [CrossRef]

29. Foudazi, R.; Qavi, S.; Masalova, I.; Malkin, A.Y. Physical chemistry of highly concentrated emulsions. Adv. Colloid Interface Sci. 2015, 220, 78-91. [CrossRef] [PubMed]

30. Naranda, J.; Sušec, M.; Maver, U.; Gradišnik, L.; Gorenjak, M.; Vukasović, A.; Ivković, A.; Rupnik, M.S.; Vogrin, M.; Krajnc, P. Polyester type polyHIPE scaffolds with an interconnected porous structure for cartilage regeneration. Sci. Rep. 2016, 6, 1-11. [CrossRef]

31. Paljevac, M.; Gradišnik, L.; Lipovšek, S.; Maver, U.; Kotek, J.; Krajnc, P. Multiple-Level Porous Polymer Monoliths with Interconnected Cellular Topology Prepared by Combining Hard Sphere and Emulsion Templating for Use in Bone Tissue Engineering. Macromol. Biosci. 2018, 18, 1-8. [CrossRef] [PubMed]

32. Busby, W.; Cameron, N.R.; Jahoda, C.A.B. Emulsion-derived foams (PolyHIPEs) containing poly(Se-caprolactone) as matrixes for tissue engineering. Biomacromolecules 2001, 2, 154-164. [CrossRef] 
33. Owen, R.; Sherborne, C.T.; Green, N.H.; Reilly, G.C.; Claeyssens, F. Emulsion templated scaffolds with tunable mechanical properties for bone tissue engineering. J. Mech. Behav. Biomed. Mater. 2016, 54, 159-172. [CrossRef]

34. Choudhury, S.; Fitzhenry, L.; White, B.; Connolly, D. Polystyrene-co-divinylbenzene polyHIPE monoliths in $1.0 \mathrm{~mm}$ column formats for liquid chromatography. Materials 2016, 9, 212. [CrossRef] [PubMed]

35. Kovačič, S.; Krajnc, P. Macroporous monolithic poly(4-vinylbenzyl chloride) columns for organic synthesis facilitation by in situ polymerization of high internal phase emulsions. J. Polym. Sci. A Polym. Chem. 2009, 47, 6726-6734. [CrossRef]

36. Huš, S.; Kolar, M.; Krajnc, P. Separation of heavy metals from water by functionalized glycidyl methacrylate poly (high internal phase emulsions). J. Chromatogr. A 2016, 1437, 168-175. [CrossRef]

37. Taylor-Pashow, K.M.L.; Pribyl, J.G. PolyHIPEs for Separations and Chemical Transformations: A Review. Solvent Extr. Ion Exch 2019, 37, 1-26. [CrossRef]

38. Krajnc, P.; Leber, N.; Štefanec, D.; Kontrec, S.; Podgornik, A. Preparation and characterisation of poly(high internal phase emulsion) methacrylate monoliths and their application as separation media. J. Chromatogr. A 2005, 1065, 69-73. [CrossRef]

39. Koler, A.; Paljevac, M.; Cmager, N.; Iskra, J.; Kolar, M.; Krajnc, P. Poly(4-vinylpyridine) polyHIPEs as catalysts for cycloaddition click reaction. Polymer 2017, 126, 402-407. [CrossRef]

40. Kawada, K.; Okano, K.; Iskra, J.; Krajnc, P.; Cahard, D. SelectfluorTMon a PolyHIPE Material as Regenerative and Reusable Polymer-Supported Electrophilic Fluorinating Agent. Adv. Synth. Catal. 2017, 359, 584-589. [CrossRef]

41. Sevšek, U.; Brus, J.; Jeřabek, K.; Krajnc, P. Post polymerisation hypercrosslinking of styrene/divinylbenzene poly(HIPE)s: Creating micropores within macroporous polymer. Polymer 2014, 55, 410-415. [CrossRef]

42. Schwab, M.G.; Senkovska, I.; Rose, M.; Klein, N.; Koch, M.; Pahnke, J.; Jonschker, G.; Schmitz, B.; Hirscher, M.; Kaskel, S. High surface area polyHIPEs with hierarchical pore system. Soft Matter. 2009, 5, 1055-1059. [CrossRef]

43. Israel, S.; Gurevitch, I.; Silverstein, M.S. Carbons with a hierarchical porous structure through the pyrolysis of hypercrosslinked emulsion-templated polymers. Polymer 2015, 72, 453-463. [CrossRef]

44. Koler, A.; Pulko, I.; Krajnc, P. Post polymerisation hypercrosslinking with emulsion templating for hierarchical and multi-level porous polymers. Acta Chim. Slov. 2020, 67, 349-360. [CrossRef]

45. Lee, J.Y.; Wood, C.D.; Bradshaw, D.; Rosseinsky, M.J.; Cooper, A.I. Hydrogen adsorption in microporous hypercrosslinked polymers. Chem. Commun. 2006, 2670-2672. [CrossRef] [PubMed]

46. Macintyre, F.S.; Sherrington, D.C.; Tetley, L. Synthesis of ultrahigh surface area monodisperse porous polymer nanospheres. Macromolecules 2006, 39, 5381-5384. [CrossRef]

47. Rouquerol, J.; Avnir, D.; Fairbridge, D.H.; Everett, C.W.; Haynes, J.M.; Pernicone, N.; Ramsay, J.D.F.; Sing, K.S.W.; Unger, K.K. Recommendations for the characterization of porous solids. Pure Appl. Chem. 1994, 66, 1739-1758. [CrossRef]

48. Harkins, W.D.; Jura, G. Surfaces of Solids. XI. Determination of Decrease (pi) of Free Surface Energy of a Solid by Adsorbed Film. J. Am. Chem. Soc. 1944, 66, 1356-1362.

49. Gregg, S.J.; Sing, K.S.W. Adsorption, Surface Area and Porosity; Academic Press: New York, NY, USA, 1982. [CrossRef] 